\title{
Sensation and Metaphor in Ritual Performance The Example of Sacred Texts
}

\author{
JAMES W. WATTS \\ Syracuse University, United States
}

\begin{abstract}
Rituals obviously utilize the human senses. Theological and mystical interpretations frequently comment on sensation as a source of metaphors for religious experience. However, the discourse used in religious rituals themselves usually avoids using the normal vocabulary appropriate to particular sensations, while focusing on ritual performance instead. This raises the question of whether it is generally the case that ritualizing sensation diverts attention from sensation to ritual behavior, and whether ritual interpretations usually divert attention from the sensation to its metaphorical meaning. This essay addresses these questions with the analytical tools of metaphor theory and ritual theory. To test and apply these theories, it focuses on one kind of ritual practices, those that involve written texts, especially books of scripture, and how they use the senses of sight, hearing, and touch.
\end{abstract}

KEYWORDS ritual, metaphor, senses, sensation, books

\section{Introduction}

Augustine, in his Confessions, wrote about his conversion to Christianity this way:

These were my words, and in grief of heart I wept bitterly. And look! - from the house next door I hear a voice-I don't know whether it is a boy or a girl—singing some words over and over: "Pick it up and read it, pick it up and read it!" ["tolle lege, tolle lege."] Immediately my expression transformed. I started to ask myself eagerly whether it was common for children to chant such words when they were playing a game of some kind. I could not recall ever having heard anything quite like it. I checked the flow of my tears and got up. I understood it as nothing short of divine providence that I was being ordered to open the book and read the first passage I came across...In great excitement I returned to the place where Alypius was sitting, for when I stood up I had put down a volume of the apostle there. I snatched it up, opened it, and read silently the first chapter that my eyes lit 
upon: "Not in partying and drunkenness, not in promiscuity and shamelessness, not in fighting and jealousy, but clothe yourself in the Lord Jesus Christ and make no provision for the flesh concerning its physical desires [Romans 13:13-14]." I neither wanted nor needed to read further. Immediately, the end of the sentence was like a light of sanctuary poured into my heart; every shadow of doubt melted away (Augustine 2014, Book Eight, Chapter 12, paragraph 29, 409-10).

This famous passage describes an immaculate conversion. I call it 'immaculate' because it is, by Augustine's account, unmediated by any human testimony or evangelist. His conversion is mediated only by the miraculous intervention of overheard voices and the apostle's written text. Augustine interprets the children's yells as a divine command to read the text, and the sacred text acts on him independently of any human intervention or direction.

Augustine's description lingers over the children's voices, but gives no details at all about the written text. Is it a scroll or a codex? Is it in Latin or Greek? Is it only Romans or a collection of all of Paul's letters? The Confessions gives us no hint. Augustine's actions-to randomly open and read a sacred text as a divine message intended immediately for himself-is a well-known and widely practiced ritual of divination: sortes Biblicae or, in current Christian slang, "bible dipping" (Malley 2013, 332). ${ }^{1}$ But Augustine provides no description of what he saw with his eyes or felt with his fingers, as if the text communicated its message unmediated by any sensation whatsoever.

That is typically how people describe messages they find in books. It is also typical of how they describe participating in a wider variety of rituals. Rituals obviously utilize the human senses, either by engaging them with art, music, and incense, for example, or by depriving them, such as in silent meditation. Mystical interpretations frequently comment on sensation as a source of metaphors for religious experience. However, the discourse around the practice of religious rituals usually avoids using the normal vocabulary appropriate to a particular sensation. For example, the rich vocabulary for describing the taste of wine does not seem appropriate for describing the wine of Christian ritual. After receiving Communion, it would sound strange to comment on the wine's quality and 'bouquet.'

Rituals use sensations, but rarely focus participants' attention on the sensation itself. Rituals focus on the actions or behaviors that produce the sensation, and so redirect attention from the experience of sensation to the experience of ritual action instead. Ritualizing sensation seems to divert attention from sensations to ritual actions and their metaphorical meanings.

There is, therefore, a three-way divergence between (1) the sensations promoted by rituals, (2) ritual discourse that focuses on ritual actions rather than sensation, and (3) second-order metaphorical rhetoric about ritual effects. Ritualizing sensation diverts attention from the sensation to focus attention on key ideas and the participants' acceptance of those ideas and the ritual's significance for their relationships to each other. When it comes to interpreting rituals, sensation gets replaced by metaphors for sensation.

In what follows, I defend these claims by discussing theories of ritualization and of metaphor and how they apply to one kind of ritual action. I begin by reviewing contemporary ritual theories. But ritual theory has not consistently engaged the relationship between sensation and metaphor. So I review theories of metaphorical meaning and place them in dialogue with ritual theories of performance. Then I test both sets of theories against a particular kind of

$1 \quad$ As Malley pointed out, such divination was commonly practiced in classical Antiquity with the works of Homer or Virgil. See also Van der Horst (1998); Parmenter (2013, 85). For similar practices among Sikhs, see Myrvold (2013, 273-74). 
ritualized action. This essay focuses on the kind of ritual practice at work in Augustine's account of his own conversion, namely, rituals using written texts, especially books of scripture. Rituals with iconic books have been the subject of much of my own research. I will discuss how ritualizing scriptures engages people's senses of sight, hearing and touch in ways that divert attention from aesthetic appreciation of these senses. I suggest that the tendency to use metaphors in ritualizing texts also appears in many other kinds of rituals as well.

\section{Ritual Sensation and Performance}

The subject of ritual has played an increasingly prominent role in the modern study of society, culture, and religions (for a detailed survey, see Bell 1997, 1-83). For present purposes, it is enough to review this literature for comments on metaphor and sensation in ritual performance.

For many years, modern theories of ritual focused attention on the ritual's role in maintaining social order and hierarchy (e.g. Smith [1889] 1907; Durkheim 1912; Douglas 1966; Geertz 1973) and on the patterned structure of ritual activity (e.g. Freud 1907; Van Gennep 1909; Lévi-Strauss 1971). The linguistic turn of the 1960s and '70s brought serious consideration of metaphors into ritual studies. Stanley J. Tambiah (1968) normalized "magical" language by pointing out that its use of metonymy and metaphor resembled their function in everyday language. Metaphors function in ordinary ways in magical and religious rhetoric. Edmund Leach, drawing on the linguist Roman Jakobson (1956), argued that many types of behavior, including rituals, establish metonymical relationships, in which a part represents the whole, but their meaning lies in their metaphorical representation of something else entirely. Ritual, then, is one of many kinds of social behavior that generate such metaphors (Leach 1976).

Ritual studies took a new and decisive turn in the 1980s, when attempts to define rituals gave way to more performative approaches to the topic, anticipated by the anthropological work of Victor Turner (1969). Ritual studies became a distinguishable academic field (Grimes 1990, 1995), and refocused academic analysis on processes of 'ritualizing' and their social effects. Catherine Bell classified ritual activities under categories that included formalism, traditionalism, invariance, rule-governance, sacral symbolism, and performance (Bell 1997, 138-69). Jonathan Z. Smith, drawing on older observations by Freud (1907) and Lévi-Strauss (1971), analyzed the essence of ritualizing as focusing people's attention by turning ordinary activities into special ones (J. Z. Smith 1987a, 193-95, 1987b, 103). Ritualizing everyday routines, such as walking into a room, eating a meal, and even breathing, turns them into meaningful practices by focusing attention on them, by formalizing them, and often by dictating how they should be done. Rituals, then, distinguish themselves from ordinary activities by drawing attention to the performance of these activities.

In particular, ritualizing serves to index participants and call attention to a social or religious ideology, according to Roy Rappaport $(1999,145)$. By “indexing," Rapport was utilizing C. S. Peirce's ([1867] 1982) language of signs to describe the social identities and relationships created and maintained by rituals. Funerals, weddings, and graduation ceremonies, for example, index the relationship between the principal ritual actors and with the audience. But rituals may also index someone's relationship to doctrine or ideology. Taking communion in a Catholic mass may index one's acceptance of Catholic dogma-or maybe not. At this point, different interpretations of ritual significance can generate controversy.

Ritualizing necessarily involves bodily sensations: the sights and sounds of walking in pro- 
cession, the taste of food and drink, the feel of inhalations and exhalations. Ronald Grimes described how different rituals organize the sensorium differently. He distinguished between traditions of ritual on the basis of their gestural metaphors:

Gestures are metaphors of the body; they display the identifications one makes and therefore is....Sitting and eating are not just activities of Buddhists and Christians; they are stylistic aspirations. Hence, they tend to modify, adverbially as it were, related actions in the same ritual system and sometimes even actions outside the system. Not only do paradigmatic gestures lead to, or reinforce, particular values, liabilities, and lifestyles, they generate corresponding thought and feeling patterns (Grimes 1995, 101-2).

On the basis of these ritual theories, we might be tempted to say that ritualization calls attention to sensation. But is it really sensation on which ritualizing focuses attention, or something else associated with the sensation by metaphor?

Rhetoric about rituals tends to name the rituals and evaluate them in emotional language ('It was a beautiful wedding'; 'the sermon was very moving'; 'I felt so proud to see you graduate'). These evaluations focus on what the ritual does and how well it was performed, that is, on action rather than immediate sensation. That tends to be the case even in meditation exercises that call explicit attention to the sensation of breathing by focusing on inhalation and exhalation. The instructions for such exercises usually equate breathing with emotion or make analogies between the sensation of breathing and other senses. They may equate exhalation with relaxation, with releasing stress, with letting go of preoccupying thoughts, and maybe with 'centering' oneself. Or attention to the feeling of breathing leads to reclassifying it as "inner sight," on analogy with another sense entirely (see, for example, Zarrilli 2015, 122). The rhetoric around breath in meditation turns the sensation of breathing into a metaphor for another sensation or an emotion.

Ritual rhetoric in this way treats sensation like other kinds of media. Birgit Meyer observed that, rather than calling attention to how they use media, many contemporary rituals convey technologically mediated experience as the real experience itself: "These media rather seem to vest the mediation in which they take part with some sense of immediacy....Practices of religious mediation appear particularly able to invoke a sense of the immediate presence of the divine" (Meyer 2011, 25-26; citing Luhmann 1997). She developed the theoretical category of "sensational forms" that "invoke sensations by inducing particular dispositions and practices towards these forms" and "which govern a sensory engagement of humans with the divine and each other" (Meyer 2009, 13). Meyer therefore stressed that sensation plays a vital role in religious experiences that seem immediate but are always culturally, materially and bodily mediated.

Verbalizing the sensory experiences produced by religious rituals requires translating them into ideas and therefore regularizing them by prevailing doctrines. Those doctrines include conventional descriptions of the senses themselves, which vary from one culture to another (Howe 2015). Mystical writings do not escape this problem of how to translate sensory experience into language, and the academic study of religion has now inherited this conundrum.

\section{Ritual Sensation and Metaphor}

Whereas ritual theory is a product of the interest of recent decades in performance, ritual 
spaces, and the bodies that perform rituals, theories of metaphor have their roots in the ancient and continuing discipline of rhetoric. Rhetoric naturally draws attention to words, so metaphors and other symbols have traditionally been treated in theories of language. Aristotle already discussed metaphors in both his lectures on Rhetoric and on Poetics (Aristotle 1954, 1404b, 1411b-1413a, 1457b), and regarded their use as reflecting education and intelligence: "It is characteristic of a well-directed mind to observe the likeness even in things very different." He added that keen observations and witty comments "come through metaphor and from an added surprise" (Aristotle 2007, 223). Discussions of metaphor as well as metonymy remained a staple topic for ancient rhetorical theorists (see Lausberg 1998, 250-64). Similarly, Kenneth Burke, a major influence on the twentieth-century revival of rhetorical studies, defined proverbial metaphors as a "strategy for dealing with a situation" (Burke 1957, 256).

It is not quite correct, however, to locate ritual metaphors just in the verbal instructions or interpretations of ritual actions. The association between a ritual sensation and its analogy in emotion or belief may be embodied rather than verbalized. Developments in metaphor theory over the past forty years have shown that bodily experience generates the metaphors that underlie almost all thought.

The theoretical discussion of metaphors has become a rich interdisciplinary discussion over the past half-century, with major contributions from anthropologists, philosophers, linguists, and cognitive psychologists. One significant strand of this enlarged discussion has challenged whether symbols, and especially metaphors, work only at the linguistic level. These theorists have suggested that, in one way or another, sensory and social experiences generate metaphors directly. There has been a gradual epistemological shift in recent decades away from theories of ritual and metaphor based on linguistic theories, such as those of Ferdinand de Saussure (1916), to theories that emphasize performance and experience, which frequently invoke the semiotic theories of C. S. Peirce instead ([1867] 1982; see Drucker 1994; Keane 2003; Engelke 2007, 29-33; Boivin 2009, 280).

An early proponent of this shift was the anthropologist Victor Turner. On the basis of ethnographic fieldwork among the Ndembu of Zambia, Turner described symbols as simultaneously conveying two kinds of meaning: the "ideological pole" of conscious norms and ideals and the "sensory pole" of sensory and emotional associations. The sensory pole brings together "the grossly physical and the structurally normative, the organic and the social....Norms and values, on the one hand, become saturated with emotion, while the gross and basic emotions become ennobled through contact with social values" (Turner 1967, 29-30). Turner noted that verbal explanations, both by members of the culture and by outside observers, emphasize the ideological pole of a symbol's meaning but struggle to comprehend and express the sensory pole. Rituals may regularly evoke emotions such as joy, pain, fear, and rivalry that are plain to participants and observers, even though their verbal expressions do not take them into account (Turner 1967, 39).

Other anthropologists also drew conclusions about metaphor from ethnographic research. James W. Fernandez, through his analysis of Fang culture and religion in Western Africa, distinguished rhetorical metaphors, used for persuasion, from performative metaphors that direct behavior. Thus, he concluded that "rituals are the acting out of metaphoric predication" (Fernandez 1972, 56). Similarly, Frederick Barth, on the basis of fieldwork with the Baktaman people of New Guinea, argued that rituals make use of inherent connections between forms and meanings which are not necessarily internally coherent or consistent. Barth observed that "the essence of metaphor is the use of the familiar to grasp the elusive and unrecognized, 
rather than the mere ordering of phenomena by homology" (Barth 1975, 199; Boivin 2009, 275-77).

George Lakoff and Mark Johnson, a linguist and philosopher, respectively, developed a far-reaching theory that metaphors constitute almost all human thought (Lakoff and Johnson 2003, 1999). This "cognitive science" reduced the most basic forms of human reasoning and sensory analysis to underlying metaphors rooted in bodily and social experience. Lakoff and Johnson attributed these basic metaphors to the physiological structure of the brain. Neurons that customarily fire at the same time develop physical connections. They argued, therefore, that analogies generated by simultaneous experiences actually become hard-wired in human brains (Lakoff and Johnson 2003, 256). This theory maintains that, though cognition is largely determined by culture, it is based in bodily metaphors generated by common experiences, such as humans' erect stance that conditions us to think of "up" and "erect" as positive and healthy (Lakoff and Johnson 2003, 14-17). Most attempts in the last thirty years to theorize metaphor have taken Lakoff and Johnson's cognitive theory as a starting point (Schmitt 2014, 15-16).

Other theoretical traditions have joined and reinforced this focus on embodied metaphors. Matthias Junge (2014), for example, applied to metaphor theory the dramaturgical theories of sociologist Erving Goffman (1959), who distinguished social actions that take place "on stage" from what goes on "behind the stage." This distinction between what one says and what one means emphasizes that social actions as well as statements are in fact metaphorical actions because they presuppose the difference between statement and meaning, and also their connection. Junge $(2014,277)$ generalized this point to assert that, from a sociological perspective, all social actions are metaphorical actions. Affect theory, developed out of a very different intellectual tradition, also joins cognitive science in emphasizing that culturally conditioned affects rise from embodied experiences, which are common not only to humans but to many animals as well (Schaefer 2015, 39, 56-57).

In another development, the archeologist and anthropologist Christopher Tilley extended the reach of metaphors from human bodies to human artifacts. He suggested that speech itself is an artifact:

Cognition is essentially a process of seeing something as something and this is the core of metaphorical understanding. Seeing something as something is grounded in culturally mediated bodily experiences. ... By taking metaphor out of language and into artefacts, we may hope to appreciate its significance in a rather different manner (Tilley 1999, 34-35).

Tilley applied these insights to both ethnography and archeology.

Nicole Boivin concluded from such studies as well as her own ethnographic fieldwork that material metaphors address "a non-linguistic side to understanding" (2009, 280-81). She argued that material culture and ritualization both generate metaphors that shape human thought and "enable bodily understanding." Language, of course, plays an important role in propagating metaphors, but

ritual activity and material culture are able to evoke such comparisons at a deeper and more physical level that seems to enable elusive concepts to be understood, and cosmological belief systems to be felt rather than just understood. Ritual and material culture ... probably better address the somatic experiences of pain, grief, confusion, and joy (Boivin 2009, 283). 
Like Lakoff and Johnson who explored the metaphorical underpinnings of science and mathematics, Tilley, Boivin, Junge, and Schaefer found that embodied metaphors shape the most developed forms of human thought, including cosmologies.

These studies show that embodied metaphors get generated by ritual experiences, among other things. Rituals produce repeated sensations that create a gestalt, a group of metaphors associated by common and repeated experiences (Lakoff and Johnson 2003, 234). Rituals also attach particular metaphors to people and things that they then carry with them into other social situations (Reul 1987, 111; Junge 2014, 279). These observations allow us to reformulate our initial observations about ritualizing the senses. Sensory experience lies behind metaphors, but sensations get processed consciously and unconsciously through their regular association with other experiences. In the same manner as many other bodily and social experiences that are repeated regularly, rituals focus attention not on the sensation itself but on its metaphorical associations.

\section{Reading Books without Seeing Them}

The analysis of book rituals illustrates the implications of theories of embodied metaphors for understanding how rituals use sensation. Now, books may seem like a strange choice to show the non-verbal role of sensation and metaphor in ritual. Books, after all, are verbal objects. They are defined by the written language they contain.

Books, however, do not just consist of language. Unlike verbal language, they are also material artifacts. Certain books, such as many religious scriptures, are widely recognized ritual objects. These sacred texts often take stereotypical forms, get manipulated in religious rituals and secular ceremonies, such as taking oaths of office, and are depicted frequently in art and other visual media. Books therefore regularly engage three human senses (sight, hearing, and touch, in the conventional Western enumeration of the senses) rather than just hearing, as verbal language does, and they sometimes engage smell and taste as well (see the essays in Watts 2018b). Books are also very common. Most people will be familiar with at least some ritual uses of them. So books and other written texts provide a common sensory experience upon which to reflect about the role of sensation in ritual.

Reading depends on the sense of sight and often touch, when we hold a book or other kind of text. Normal reading, however, sublimates sensation to meaning by taking no conscious notice of the look of the signs or the feel of the book. Instead, we have been trained by years of literacy education to focus on the meaning of the words alone.

This tendency has been reinforced by the conscious labors of type designers. Over many centuries, they have worked to make printed text virtually invisible while readers pay conscious attention to only the words and ideas it conveys (Bringhurst and Chappell 1999; Plate 2013, 121). Their achievements perfect the original genius of writing, which is to convey immaterial ideas and oral language by means of visual signs. Written texts work by drawing attention away from their visual appearance to their semantic meaning instead. Reading, then, is a paradigmatic example of how technology and socialization encourage us to ignore sensation and to concentrate instead on the action of reading and the immaterial ideas that arise from it. To paraphrase Birgit Meyer's words, books mediate a sense of immediacy.

Textual rituals, however, call attention to sensory input that normal reading leaves subconscious. Ritualizing books draws attention to the sight of handwriting and printed type, to page layouts and the shapes of scrolls and codices, to the sounds of recitations, and to the 
social processes of interpretation. Each of the three textual dimensions (iconic, expressive, and semantic) gets ritualized in different ways (Watts 2013). While ritualizing the semantic dimension through preaching and commentary reinforces a focus on meaning rather than sensation, ritualizing the expressive dimension draws attention to the sound of the words, ${ }^{2}$ while ritualizing the iconic dimension draws attention to visual and tactile interactions with books.

\section{Viewing Books without Reading Them}

Let me give some examples. Elaborate bindings (e.g. medieval jeweled Gospel covers), fanciful scripts (e.g. Arabic decorative calligraphy), and beautiful illustrations (e.g. Renaissance Books of Hours) all draw attention and elicit a great deal of admiring commentary about how they look. Such aesthetic commentary, and its contribution to the increased prestige of books and their owners, might seem to be the purpose of such decorations. That is certainly the case in exhibits of books created by libraries and museums, which use them to increase attention to their institutions. They can also use the aesthetic appeal of beautiful books to convey explicit religious and political messages.

For example, in the first decade of the twenty-first century, book displays became a prominent means for positively comparing religious traditions. The attacks in New York on September 11, 2001, and the U.S. invasions of Afghanistan and Iraq beginning in 2002, fueled fear and distrust of Muslims in Western countries. To counter these prejudices, libraries created exhibits portraying the common cultural heritage of books and scriptures in Christianity, Judaism, and Islam. In 2005, the Bibliothèque Nationale de France in Paris staged "Torah, Bible, Coran: Livres de parole" (Berthier and Zali 2005). In 2007, the British Library in London exhibited "Sacred: Discover What We Share" ("Sacred: Discover What We Share." n.d.). Then, in 2010, the New York Public Library staged "Three Faiths: Judaism, Christianity, Islam" ("Three Faiths: Judaism, Christianity, Islam" n.d.). All three exhibits placed medieval and early modern Torah scrolls and codices, copies of the Qur'an, and gospels and bibles next to each other to show how the three religions adopted common strategies for decorating and venerating the iconic dimension of their scriptures. All three exhibitions were overtly intended to promote pluralism and religious tolerance in twenty-first-century societies.

There can be no question that these displays drew attention to visual sensation. The books could not be touched in their display cases, and most viewers could not read much, if any, of the scripts of these Hebrew, Arabic, Greek, and Latin books. Nevertheless, the exhibits depended on implicit sensory metaphors. The libraries' museum-style exhibits ritualized the books' iconic dimension through the aesthetic conventions of art museums. These cultural conventions depend on the root metaphor that beautiful objects are good and valuable objects, and that comparable beautiful objects in different religious cultures show the equivalent value of them all.

Such exhibits clearly emphasize and utilize the aesthetics of visual sensation-more so than does the typical ritualization of scriptures by religious congregations and individuals. Comments about rich visual sensation belong to library displays, museums, and religious sites

2 The expressive dimension was called the "performative" dimension in Watts (2013). However, that terminology risks confusion with theories of performativity that describe all kinds of ritual behavior and much else besides (see below). The "expressive" dimension points more narrowly to the ways in which we express the contents of texts through reading aloud and silently, and through song, art, theater, and film. 
functioning as tourist attractions, more than in religious congregations. Within a sacred text's ritual context in a religious community, however, the same decorative script and stereotypical book-forms do not usually draw as much commentary about aesthetic sensation. Instead, their distinctiveness and beauty are aesthetic metaphors for their truth, their religious value, and their sacred status.

Apart from that ritual context, they may not evoke the same veneration. For example, Natalia Suit observed that the staff of a Cairo library treated beautiful old manuscripts of the Qur'an with less care than Egyptian Muslims commonly treat their scriptures. After being moved to a museum, the manuscripts were preserved and displayed better, but now as objects of aesthetic appreciation (Suit 2013, 193-94). Mass-produced copies of the Qur'an are not as rare or distinctive, but in the hands of devout Muslims are more likely to be regularly ritualized in their iconic, expressive, and semantic dimensions as scripture. Their ritualization in all three dimensions gets reflected in language as the piety of devotional actions. The language of aesthetic visual appreciation does not belong here, but only in a museum or private rare book collection.

\section{Singing Books without Hearing Them}

Within religious congregations, ritualizing the expressive dimension of sacred texts by hearing the sounds of scripture readings, recitations, cantillations, and songs is more likely to provoke aesthetic commentary than is the iconic dimension. Participants may remark on the beauty of the performance and the emotional impact of hearing the scriptures recited or sung. Here, even though congregations may frown on paying too much attention to the performers, aesthetic appreciation is sometimes barely forestalled. For example, applause for performers is becoming more common in American Christian churches (James 2018, 106, 312). In other congregations, applause can be controversial, though perhaps allowed after the worship service has concluded.

In Western culture, this tendency to aestheticize the performance of scriptural texts has become institutionalized by the performance of religious music in concert halls. It has led to the composition of musical scores with scriptural texts intended primarily for concert hall performances. A famous example of this trend is Georg Frideric Handel's oratorio, The Messiah. With a libretto consisting entirely of biblical texts, it premiered in 1742 in a concert hall, not a church (Jacobi 1982). Such concert settings continue to ritualize scriptural texts in the expressive dimension, but unaccompanied by religious interpretation or any visible sign of the Bible itself. Like museum exhibits of old manuscripts, the words of such concert performances ritualize only one of the three textual dimensions. The text continues to inspire in this context, but no longer as a fully functioning scripture (Watts 2017, 154-55). Congregations, however, have adopted The Messiah and other concert music with scriptural and religious themes to perform in churches, where they are reinforced by the ritualization of scripture in the other dimensions as well.

Some other religious communities have traditionally called attention to the aesthetic sensation of hearing the words of scripture. The beauty and emotional intensity of Qur'anic recitations has been widely celebrated since its origins (Graham 1987, 85-112; Rooke 2006, 219). Similarly, commentary on the cosmic power of the sounds of Vedic recitations has played a decisive role in the development and continuing power of South Asian religious traditions (Coburn 1984; Graham 1987, 70-71). Ritualizing the expressive dimension inspires listeners 
and performers, and they tend to project this experience of inspiration onto the text itself, which they regard as supernaturally inspired (Watts 2013, 22). Ritualization of the expressive dimension is therefore more likely to inspire verbal statements of aesthetic appreciation of sensation than are the other two dimensions of scriptures. That is because the performers can be singled out to praise their aesthetic skills, while the scripture is celebrated for its spiritually inspiring and even cosmic, but not sensory, effects.

\section{Touching Books without Feeling Them}

The aesthetics of touch is less commonly discussed than that of the other senses. It has, until recently, been precluded from the aesthetic practices and commentary traditions of concert halls and art museums (Ganz 2018, 84-85). There are exceptions: some museums invite visitors to feel the touch of blank parchment sheets to compensate for the fact that their exhibits prevent visitors from touching medieval books in the normal way (Watts 2018a, 179). The religious effects of touching scriptures do not receive much attention from traditional scholars within religious traditions either, except to prohibit misusing the sacred texts (Wilkens 2018, 121-27). The sensory effects of touching sacred texts remains restricted to the religious practices of devout individuals and congregations. In that sphere, however, they are quite common and widely practiced.

Examples of touch as a means of connecting with scriptures range from people reaching out to touch a book of scripture as it is processed in synagogues and churches to the widespread practice of carrying a volume of scripture and displaying it in homes and religious buildings. Even more widespread in many cultures around the world is the practice of touching and wearing amulets containing scriptural texts. The rhetoric around such practices does not emphasize sensation (e.g. how the book feels) but rather its effects (e.g. the blessing desired by making contact with the holy object). Touching scriptures functions religiously very much like touching other kinds of holy objects, such as icons and relics (Parmenter 2013, 63-67, 81-84; Watts 2013, 12, 28-30).

This tendency to divert attention from the sensation of touch to the religious transaction indexed by touching is emphasized, for example, by the Jewish tradition of mediated touch (Green 1999, 1304; Schleicher 2018, 49-51). Readers use a pointer rather than their finger to direct their eyes to the correct line in a Torah scroll so as to avoid touching the sacred letters. When members of a congregation reach out to the passing Torah scroll, they touch it with the tassels of their tallits (prayer shawls) or their siddurs (prayer books), rather than with their fingers. Thus, in these traditional practices, there is little sensation of touching the books themselves, but that does not interfere with the hope that the scripture's power to bless functions through mediated touch.

Touching books also plays a major role in Tibetan Buddhist rituals. Touching a sutra to one's head or forehead indicates respect, and also is believed to convey blessings or consecration (Cantwell 2018, 145). A lama may place a tantric text or written mandala on a student's head, throat, or heart to imbibe the Buddha word. A sutra or collection of sutras may be processed around a village and its fields to invoke fertility, health, and prosperity (Cantwell 2018, 147). Tibetan Buddhists understand these practices as transmitting the Dharma, the essence of Buddhist teachings.

As in these examples, touching and holding scriptures generally does not evoke the language of sensation. When someone holds a book of scripture, we do not usually ask, 'How does the 
book feel?" Instead, we ask about the feelings evoked by the ritual's purpose, whether its purpose is devotion, inspiration, conversion, divination, ordination, or inauguration. Thus, in the example quoted at the beginning of this article, Augustine did not report the sight or feel of the book when describing his conversion to Christianity by reading Paul's letter to the Romans. He instead described an internal sensation, "a light of sanctuary poured into my heart, every shadow of doubt melted away." "This sensory analogy mixed the feeling of drinking a hot liquid that spreads its warmth through his body with seeing the light of dawn spread across a landscape. Augustine evoked and mixed two common metaphors of reading as consumption and reading as enlightenment. The book acts on the passive reader like drink acts on the human body and like light affects the eyes.

A modern example of how sensory impulses generate ritual practices with scriptures appears in the bindings and covers for bibles. Distinctive bible bindings and covers in leather or cloth cultivate the sense of touch as much as sight. To ask about the meaning of leather bindings for bibles or other books makes the mistake of thinking meaning must reside in verbal formulation. Christian tradition provides no verbal interpretation of the meaning of leather-bound bibles because the meaning lies in the sensation itself. The leather-bound book does not represent intimacy. Rather, the touch of skin to skin feels intimate. In the same way, handling a leather- or cloth-bound Bible does not represent intimacy with the divine. It enacts intimacy with the divine through its material manifestation-for many (Protestant) Christians in the only material object that they regard as holy. Holding the Bible enables one to touch the divine. But putting it into these words immediately sounds wrong, because it is not a verbal experience, but rather a sensation. Therefore Christian practices and rituals do not verbalize this analogy, but leave it to function at the sensory level alone. This sensory metaphor is nevertheless culturally shaped: the touch of leather can provoke a very different reaction in cultures that regard dead skin as unclean.

Touching scripture, whether mediated or not, also functions as a means of indexing one's religious identity by identification with the scripture. This is most obvious in religious art and portraiture, which often depict people holding a scripture to represent their piety, orthodoxy, and scholarship. Common metaphors for the effects of reading books speak about touchingbut not about people touching books, rather about books touching people (Watts 2018a). In common language, reading books leads to the books' influence on the reader, rather than the other way around. Religious language amplifies this effect through beliefs that a deity or ultimate reality can influence readers by means of sacred texts (e.g. Augustine).

\section{Conclusion}

Ritualizing books as scriptures thus utilizes sight, sound, and touch to reinforce people's religious identity. Ritualization diverts the sensation of seeing, hearing, and touching the book into feelings of inspiration and legitimacy (Watts 2013). Scriptures are symbols of their religious tradition. Touching and holding them can establish your place within that tradition, both to yourself and to anyone else who sees you do it.

Book rituals therefore do not really call attention to the sensations of seeing, hearing, and touching sacred texts. They instead focus attention on performing ritual actions by viewing, listening, and touching scriptures. And they allow devotees to feel in contact with the divine by making contact with a sacred book.

3 "Luce securitatis infusa cordi meo omnes dubitationis tenebrae diffugerunt." 
The use of theories of ritual and metaphor to analyze book rituals vindicates the observation that rituals choreograph, schematize, and dogmatize the senses, ${ }^{4}$ but with an important qualification. Ritualized sensations are usually expressed by metaphors. To summarize in the terms of cognitive metaphor theory, we can say that religious rituals reorient participants' attention from the more elaborate metaphors of doctrine and mysticism to more basic metaphors grounded in bodily sensation and the immediate social setting of the congregation. In the end, they usually aim to return attention to verbalized instructions for belief and practice. Rituals serve to ground that discourse in embodied experiences by focusing attention on metaphors of ritualized sensations. However, as is always the case with metaphors, only part of the experience gets employed by the analogies to which they contribute. Left unstated verbally are the sensations themselves, through which people feel the metaphors that identify them with their fellow congregants and, perhaps, with the religion, or with God, or with the cosmos. They are likely to verbalize that feeling of identity, but not the bodily sensations that give rise to the metaphor of identity.

\section{Acknowledgments}

The argument of this article developed in the discussions of the Focus Group Ritual of the Käte Hamburger Kolleg Dynamics in the History of Religions Between Asia and Europe in the Center for Religious Studies at Ruhr-Universität Bochum during my fellowship there in 2015-2016. I am grateful to the CERES faculty, staff, and fellows who participated in those conversations for their insights and encouragement to pursue these questions. The article has also benefitted from the comments and suggestions of the anonymous peer reviewers for Entangled Religions, though I alone am responsible for its final form and contents.

\section{References}

Aristotle. 1954. The Rhetorics and Poetics of Aristotle. Translated by William Rhys Roberts. New York: Random House.

. 2007. On Rhetoric: A Theory of Civic Discourse. Translated by George A. Kennedy. New York: Oxford University Press.

Augustine. 2014. Confessions. Translated by Carolyn J.-B. Hammond. Vols. I: Books 1-8. Loeb Classical Library 26. Cambridge, MA: Harvard University Press.

Barth, Frederik. 1975. Ritual and Knowledge Among the Baktaman of New Guinea. New Haven, CT: Yale University Press.

Bell, Catherine. 1997. Ritual: Perspectives and Dimensions. New York: Oxford University Press. Berthier, Annie, and Anne Zali. 2005. Livres de Parole: Torah, Bible, Coran. Paris: BnF Éditions. Boivin, Nicole. 2009. "Grasping the Elusive and Unknowable: Material Culture in Ritual Practice." Material Religion 5 (3): 266-87. https://doi.org/10.2752/175183409X12550007 729860.

Bringhurst, Robert, and Warren Chappell. 1999. A Short History of the Printed Word. 2nd ed. Point Roberts, WA: Hartley and Marks Publishers.

Burke, Kenneth. 1957. The Philosophy of Literary Form. Revised. New York: Vintage Books.

4 See https://khk.ceres.rub.de/en/research/focus-groups-old/ritual/ (accessed September 25, 2019). 
Cantwell, Cathy. 2018. "Seeing, Touching, Holding, and Swallowing Tibetan Buddhist Texts." In Sensing Sacred Texts, edited by James W. Watts, 137-60. Sheffield: Equinox.

Coburn, Thomas B. 1984. "'Scripture' in India: Towards a Typology of the Word in Hindu Life." Journal of the American Academy of Religion 52: 435-59.

Douglas, Mary. 1966. Purity and Danger: An Analysis of Concepts of Pollution and Taboo. New York: Praeger.

Drucker, Johanna. 1994. The Visible Word: Experimental Typography and Modern Art, 19091923. Chicago: University of Chicago Press.

Durkheim, Émile. 1912. Les formes élémentaires de la vie religieuse. Paris: Felix Alcan.

Engelke, Matthew. 2007. A Problem of Presence: Beyond Scripture in an African Church. Berkeley: University of California Press.

Fernandez, James. 1972. "Persuasions and Performances: Of the Beast in Every Body... and the Metaphors of Everyman." Daedalus 101 (1): 39-60.

Freud, Sigmund. 1907. Obsessive Actions and Religious Practices.

Ganz, David. 2018. "Touching Books, Touching Art: Tactile Dimensions of Sacred Books in the Medieval West." In Sensing Sacred Texts, edited by James W. Watts, 81-113. Sheffield: Equinox.

Geertz, Clifford. 1973. The Interpretation of Culture. New York: Basic.

Goffman, Erving. 1959. The Presentation of Self in Everyday Life. Revised. New York: Anchor.

Graham, William A. 1987. Beyond the Written Word: Oral Aspects of Scripture in the History of Religion. Cambridge: Cambridge University Press.

Green, William Scott. 1999. "Scripture in Classical Judaism." In The Encyclopedia of Judaism, edited by Jacob Neusner, s. Peck, and William Scott Green, 1302-9. New York/Leiden: Continuum/Brill.

Grimes, Ronald L. 1990. Ritual Criticism: Case Studies in Its Practice, Essays on Its Theory. Columbia: University of South Carolina Press.

— 1995. Beginnings in Ritual Studies. Revised. Columbia: University of South Carolina Press.

Howe, David. 2015. "Sensation and Transmission." In Ritual, Performance and the Senses, edited by Michael Bull and Jon P. Mitchell, 153-66. London: Bloomsbury.

Jacobi, Peter. 1982. The Messiah Book: The Life and Times of G. F. Handel's Greatest Hit. New York: St. Martin's Press.

Jakobson, Roman. 1956. "Two Aspects of Language and Two Types of Aphasic Disturbance." In Fundamentals of Language, edited by Roman Jakobson and M. Halle, 53-83. Paris: Mouton.

James, Christopher B. 2018. Church Planting in Post-Christian Soil: Theology and Practice. New York: Oxford University Press.

Junge, Matthias. 2014. "Metaphorisches Handeln: Ein konzeptioneller Vorschlag." In Methoden der Metaphernforschung und -analyse, edited by Matthias Junge, 271-81. Wiesbaden: Springer.

Keane, Webb. 2003. "Semiotics and the Social Analysis of Material Things." Language \& Communication 23: 409-25.

Lakoff, George, and Mark Johnson. 2003. Metaphors We Live By. 2nd ed. Chicago: University of Chicago Press.

Lausberg, Heinrich. 1998. Handbook of Literary Rhetoric: A Foundation for Literary Study. Edited by David E. Lorton and R. Dean Anderson. Leiden: Brill. 
Leach, Edmund R. 1976. Culture and Communication: The Logic by Which Symbols Are Connected. Cambridge: Cambridge University Press.

Lévi-Strauss, Claude. 1971. The Naked Man. Translated by John Weightman and Doreen Weightman. New York: Harper and Row.

Luhmann, Niklas. 1997. Die Gesellschaft der Gesellschaft. Frankfurt a. M.: Suhrkamp.

Malley, Brian. 2013. "The Bible in British Folklore." In Iconic Books and Texts, edited by James W. Watts, 315-47. Sheffield: Equinox.

Meyer, Birgit. 2009. "From Imagined Communities to Aesthetic Formations: Religious Mediations, Sensational Forms, and Styles of Binding." In Aesthetic Formations: Media, Religion, and the Senses, edited by Birgit Meyer, 1-28. New York: Palgrave Macmillan.

- 2011. "Mediation and Immediacy: Sensational Forms, Semiotic Ideologies and the Question of the Medium." Edited by Birgit Meyer. Social Anthropology/Anthropologie Sociale 19 (1): 23-29.

Myrvold, Kristina. 2013. "Engaging with the Guru: Sikh Beliefs and Practices of Guru Granth Sahib." In Iconic Books and Texts, edited by James W. Watts, 261-81. Sheffield: Equinox.

Parmenter, Dorina Miller. 2013. "The Iconic Book: The Image of the Bible in Early Christian Rituals." In Iconic Books and Texts, edited by James W. Watts, 63-92. Sheffield: Equinox.

Peirce, Charles S. (1867) 1982. "On A New List of Categories." In The Writings of Charles $S$. Peirce: A Chronological Edition, Peirce Edition Project, 2:49-58. Bloomington, IN: Indiana University Press.

Plate, S. Brent. 2013. "Looking at Words: The Iconicity of the Page." In Iconic Books and Texts, edited by James W. Watts, 119-33. Sheffield: Equinox.

Rappaport, Roy A. 1999. Ritual and Religion in the Making of Humanity. Cambridge: Cambridge University Press.

Reul, Malcolm. 1987. "Icons, Indexical Symbols and Metaphorical Actions: An Analysis of Two East African Rites." Journal of Religion in Africa 17 (2): 98-112.

Rooke, Tetz. 2006. "Translation of Arabic Literature: A Mission Impossible." In Current Issues in the Analysis of Semitic Grammar and Lexicon II, edited by Lutz Edzard and Jan Retsö, 214-25. Wiesbaden: Harrassowitz.

"Sacred: Discover What We Share." n.d. British Library Online Gallery. Accessed March 26, 2018. http://www.bl.uk/onlinegallery/features/sacred/review.html.

Saussure, Ferdinand de. 1916. Cours de linguistique générale. Edited by Charles Bally and Albert Sechehaye.

Schaefer, Donovan O. 2015. Religious Affects: Animality, Evolution, and Power. Durham, NC: Duke University Press.

Schleicher, Marianne. 2018. "Engaging All the Senses: On Multi-Sensory Stimulation in the Process of Making and Inaugurating a Torah Scroll." In Sensing Sacred Texts, edited by James W. Watts, 39-56. Sheffield: Equinox.

Schmitt, Rudolph. 2014. "Eine Übersicht über Methoden sozialwissenschaftlicher Metaphernanalysen." In Methoden der Metaphernforschung und -analyse, edited by Matthias Junge, 13-30. Wiesbaden: Springer.

Smith, Jonathan Z. 1987a. "The Domestication of Sacrifice." In Violent Origins, edited by Robert G. Hamerton-Kelly, 191-235. Stanford: Stanford University Press.

- 1987b. To Take Place: Toward Theory in Ritual. Chicago: University of Chicago.

Smith, William Robertson. (1889) 1907. Lectures on the Religion of the Semites. Revised edition. London: A. \& C. Beck. 
Suit, Natalia K. 2013. "Muṣhaf and the Material Boundaries of the Qur'an." In Iconic Books and Texts, edited by James W. Watts, 189-206. Sheffield: Equinox.

Tambiah, Stanley J. 1968. "The Magical Power of Words." Man 3 (2): 175-208.

"Three Faiths: Judaism, Christianity, Islam." n.d. New York Public Library. Accessed March 26, 2018. https://www.nypl.org/events/exhibitions/three-faiths-judaism-christianityislam.

Tilley, Christopher. 1999. Metaphor and Material Culture. Oxford: Blackwell.

Turner, Victor. 1967. The Forest of Symbols: Aspects of Ndembu Ritual. Ithaca, NY: Cornell University Press.

- 1969. The Ritual Process: Structure and Anti-Structure. Berlin: De Gruyter.

Van der Horst, Pieter W. 1998. "Sortes: Sacred Books as Instant Oracles in Late Antiquity." In The Use of Sacred Books in the Ancient World, edited by L. V. Rutgers, 143-73. Leuven: Peeters.

Van Gennep, Arnold. 1909. Les rites de passage. Paris: Émile Nourry.

Watts, James W. 2013. "The Three Dimensions of Scriptures." In Iconic Books and Texts, edited by James W. Watts, 8-30. Sheffield: Equinox.

- 2017. Understanding the Pentateuch as a Scripture. London: Wiley Blackwell.

—. 2018a. "Scripture's Indexical Touch." In Sensing Sacred Texts, edited by James W. Watts, 173-84. Sheffield: Equinox.

- 2018b. Sensing Sacred Texts. Sheffield: Equinox.

Wilkens, Katherina. 2018. "Infusions and Fumigations: Literacy Ideologies and Therapeutic Aspects of the Qur'an." In Sensing Sacred Texts, edited by James W. Watts, 115-36. Sheffield: Equinox.

Zarrilli, Phillip B. 2015. “ 'Inner Movement' Between Practices of Meditation, Martial Arts, and Acting: A Focused Examination of Affect, Feeling, Sensing, and Sensory Attunement." In Ritual, Performance and the Senses, edited by Michael Bull and Jon P. Mitchell, 121-36. London: Bloomsbury. 